\title{
Translation of New Molecular Imaging Approaches to the Clinical Setting: Bridging the Gap to Implementation
}

\author{
Suzanne C. van Es*11, Clasina M. Venema*1, Andor W.J.M. Glaudemans ${ }^{2}$, Marjolijn N. Lub-de Hooge ${ }^{3}$, Sjoerd G. Elias ${ }^{4}$, \\ Ronald Boellaard ${ }^{2}$, Geke A.P. Hospers ${ }^{1}$, Carolina P. Schröder ${ }^{1}$, and Elisabeth G.E. de Vries ${ }^{1}$ \\ ${ }^{I}$ Department of Medical Oncology, University Medical Center Groningen, University of Groningen, Groningen, The Netherlands; \\ ${ }^{2}$ Department of Nuclear Medicine and Molecular Imaging, University Medical Center Groningen, University of Groningen, \\ Groningen, The Netherlands; ${ }^{3}$ Department of Clinical Pharmacy and Pharmacology, University Medical Center Groningen, \\ University of Groningen, Groningen, The Netherlands; and ${ }^{4} J u l i u s$ Center for Health Sciences and Primary Care, University Medical \\ Center Utrecht, Utrecht, The Netherlands
}

\begin{abstract}
Molecular imaging with PET is a rapidly emerging technique. In breast cancer patients, more than 45 different PET tracers have been or are presently being tested. With a good rationale, after development of the tracer and proven feasibility, it is of interest to evaluate whether there is a potential meaningful role for the tracer in the clinical setting - such as in staging, in the (early) prediction of a treatment response, or in supporting drug choices. So far, only ${ }^{18} \mathrm{~F}$ FDG PET has been incorporated into breast cancer guidelines. For proof of the clinical relevance of tracers, especially for analysis in a multicenter setting, standardization of the technology and access to the novel PET tracer are required. However, resources for PET implementation research are limited. Therefore, next to randomized studies, novel approaches are required for proving the clinical value of PET tracers with the smallest possible number of patients. The aim of this review is to describe the process of the development of PET tracers and the level of evidence needed for the use of these tracers in breast cancer. Several breast cancer trials have been performed with the PET tracers ${ }^{18} \mathrm{~F}$-FDG, $3^{\prime}$-deoxy- $3^{\prime}-{ }^{18} \mathrm{~F}$-fluorothymidine $\left({ }^{18} \mathrm{~F}-\mathrm{FLT}\right)$, and ${ }^{18} \mathrm{~F}$-fluoroestradiol $\left({ }^{18} \mathrm{~F}-\mathrm{FES}\right)$. We studied them to learn lessons for the implementation of novel tracers. After defining the gap between a good rationale for a tracer and implementation in the clinical setting, we propose solutions to fill the gap to try to bring more PET tracers to daily clinical practice.
\end{abstract}

Key Words: PET; ${ }^{18} \mathrm{~F}-\mathrm{FDG}$ PET; ${ }^{18} \mathrm{~F}-\mathrm{FLT}$ PET; ${ }^{18} \mathrm{~F}-\mathrm{FES}$ PET; implementation; clinical utility

J Nucl Med 2016; 57:96S-104S

DOI: 10.2967/jnumed.115.157974

\section{$\mathbf{M}$}

olecular imaging with PET is a rapidly emerging approach in oncology. This approach offers the potential to noninvasively determine tumor staging, make tumor response measurements, and characterize relevant drug targets in the tumor. Moreover, the wholebody 3-dimensional image provides information about all tumor

Received Jul. 23, 2015; revision accepted Nov. 13, 2015.

For correspondence or reprints contact: E.G.E. de Vries, Department of Medical Oncology, University Medical Center Groningen, University of Groningen, P.O. Box 30 001, 9700 RB Groningen, The Netherlands.

E-mail: e.g.e.de.vries@umcg.nl

${ }^{*}$ Contributed equally to this work.

COPYRIGHT (c) 2016 by the Society of Nuclear Medicine and Molecular Imaging, Inc. lesions within a patient. This information is increasingly of potential interest because of progressive awareness of the existence of tumor heterogeneity for several clinical relevant characteristics $(1,2)$. Interestingly, the development of tracers for most hallmarks of cancer allows the imaging of key characteristics of tumors in the research setting (3). More than 30 different PET tracers have been analyzed for their contributions to staging or early response measurements in breast cancer (Table 1). In addition, in the past $5 \mathrm{y}$, information on 15 different breast cancer tracers has been published. Many more are expected. However, at present, only the visualization of glucose uptake with ${ }^{18} \mathrm{~F}$-FDG PET is part of standard care and has been incorporated into breast cancer guidelines $(4,5)$. New initiatives are attempting to bridge the gap between new chemical entities and clinical-grade radiopharmaceuticals, which then must be brought to the clinical setting. This process requires proof-of-concept feasibility studies; when sufficient evidence has accumulated, the tracer should be implemented in the clinical setting.

The aims of this review are to summarize the steps from preclinical to first-in-human studies and to summarize the current research on PET tracers and level of evidence (LoE) (6) concerning their contributions to the breast cancer field. We summarize the literature on ${ }^{18} \mathrm{~F}$-FDG, $33^{\prime}$-deoxy- $3{ }^{\prime}-{ }^{18} \mathrm{~F}$-fluorothymidine ( $\left.{ }^{18} \mathrm{~F}-\mathrm{FLT}\right)$, and ${ }^{18}$ F-fluoroestradiol ( ${ }^{18} \mathrm{~F}$-FES) PET studies because several breast cancer trials have been performed. Our goal is to learn lessons about the potential steps for implementing more PET tracers in clinical practice.

\section{SEARCH STRATEGY}

To gain insight into novel PET tracers being tested in breast cancer, PubMed/Medline was searched, with special attention to studies involving ${ }^{18} \mathrm{~F}$-FDG, ${ }^{18} \mathrm{~F}$-FLT, and ${ }^{18} \mathrm{~F}$-FES tracers. In April 2015, ClinicalTrials.gov was searched for ongoing clinical trials with the search terms [PET] AND [breast cancer]. In total, 164 ongoing PET studies were found.

\section{TRANSITION OF TRACERS FROM PRECLINICAL EVALUATION TO FIRST-IN-HUMAN STUDIES}

Bringing tracers from the research-and-development phase to the clinical setting can be a major challenge. Several barriers can cause inefficient translation of novel chemical entities to clinicalgrade radiopharmaceuticals; these include lack of good-manufacturingpractice facilities, lack of resources, and insufficient knowledge of the translational process and regulatory requirements. 
TABLE 1

Ongoing Trials with Experimental PET Tracers in Breast Cancer

\begin{tabular}{|c|c|c|}
\hline Tracer type & No. of ongoing trials & Target \\
\hline${ }^{18} \mathrm{~F}-\mathrm{FES}$ & 11 & $\mathrm{ER}$ \\
\hline${ }^{18} \mathrm{~F}-\mathrm{FLT}$ & 6 & ENT1/TK1 \\
\hline${ }^{18} \mathrm{~F}$-fluorocholine & 1 & ChK- $a$ \\
\hline${ }^{18} \mathrm{~F}$-fluoro furanyl norprogesterone & 1 & Progesterone receptor \\
\hline${ }^{18} \mathrm{~F}$-fluoromisonidazole & 1 & Hypoxia \\
\hline${ }^{18} \mathrm{~F}$-fluoroethoxy-5-methylbenzamide & 2 & Sig-2R \\
\hline${ }^{18} \mathrm{~F}$-fluorodihydrotestosterone & 1 & $A R$ \\
\hline${ }^{18} \mathrm{~F}$-sodium fluoride & 3 & Bone formation \\
\hline${ }^{18} \mathrm{~F}$-fluciclatide & 1 & $A_{v} \beta_{3}$ \\
\hline${ }^{18} \mathrm{~F}-\mathrm{FMAU}$ & 1 & DNA synthesis \\
\hline${ }^{18} \mathrm{~F}$-fluoroazomycin-arabinoside & 1 & \\
\hline${ }^{18} \mathrm{~F}-\mathrm{EF} 5$ & 1 & EF5 \\
\hline${ }^{18} \mathrm{~F}$-fluoride & 1 & \\
\hline${ }^{18} \mathrm{~F}$-paclitaxel & 2 & Tubulin \\
\hline${ }^{18} \mathrm{~F}$-fluorocyclobutanecarboxylic acid & 3 & \\
\hline${ }^{18} \mathrm{~F}-\mathrm{RGD}-\mathrm{K} 5$ (flotegatide) & 1 & $A_{v} \beta_{3}$ \\
\hline${ }^{18} \mathrm{~F}$-fluorobenzyl triphenylphosphonium & 1 & Perfusion \\
\hline${ }^{11} \mathrm{C}$-lapatinib & 1 & EGFR and HER2 \\
\hline${ }^{11} \mathrm{C}$-choline & 1 & ChK-a \\
\hline${ }^{89} \mathrm{Zr}$-trastuzumab & 6 & HER2 \\
\hline${ }^{89} \mathrm{Zr}$-bevacizumab & 3 & VEGF-A \\
\hline${ }^{111}$ In-trastuzumab & 1 & HER2 \\
\hline${ }^{68} \mathrm{Ga}-\mathrm{ABY}-025$ & 2 & HER2 \\
\hline${ }^{68} \mathrm{Ga}-\mathrm{IMP}-288$ & 1 & CEA \\
\hline${ }^{68} \mathrm{Ga}-\mathrm{NOTA}-\mathrm{NFB}$ & 1 & CXCR4 \\
\hline${ }^{64} \mathrm{Cu}$-DOTA-trastuzumab & 3 & HER2 \\
\hline${ }^{64} \mathrm{Cu}-\mathrm{DOTA}-\mathrm{AE} 105$ & 1 & $\begin{array}{l}\text { Urokinase plasminogen activator } \\
\text { receptor }\end{array}$ \\
\hline${ }^{64} \mathrm{Cu}$-anti-CEA & 1 & CEA \\
\hline 2-deoxy-D-glucose & 1 & GLUT-1/HKII \\
\hline ONT-10 & 1 & MUC1 lipid A \\
\hline Nonspecified & 17 & \\
\hline
\end{tabular}

ENT1/TK1 = equilibrative nucleoside transporter 1/thymidine kinase 1; ChK- $\alpha=$ choline kinase- $\alpha$; Sig-2R = $\sigma$-receptor subtype 2; $\mathrm{AR}=$ androgen receptor; $\mathrm{A}_{\mathrm{v}} \beta_{3}=$ vitronectin receptor integrin $\alpha-\mathrm{V}$ and integrin $\beta-3 ;{ }^{18} \mathrm{~F}-\mathrm{FMAU}={ }^{18} \mathrm{~F}-1$ - $\left(2^{\prime}\right.$-deoxy-2'-fluoro-Darabinofuranosyl)thymine; EF5 = 2-(2-nitro-1H-imidazol-1-yl)- $N$-(2,2,3,3,3-pentafluoropropyl)-acetamide; RGD-K5 = 2-((2S,5R,8S,11S)-5benzyl-8-(4-((2S,3R,4R,5R,6S)-6-((2-(4-(3-18 F-fluoropropyl)-1H-1,2,3-triazol-1-yl)acetamido)methyl)-3,4,5-trihydroxytetrahydro-2H-pyran-2carboxamido)butyl)-11-(3-guanidinopropyl)-3,6,9,12,15-pentaoxo-1,4,7,10,13-pentaazacyclopentadecan-2-yl)acetic acid; EGFR = endothelial growth factor receptor; VEGF-A = vascular endothelial growth factor A; ABY-025 = maleimide-DOTA-Cys61-ZHER2; CEA = carcinoembryonic antigen; NOTA-NFB = p-SCN-Bn-NOTA with T140-NFB; CXCR4 = chemokine (C-X-C motif) receptor 4; AE105 = urokinase plasminogen activator receptor antagonist; GLUT-1/HKII = glucose transporter 1/hexokinase 2; ONT-10 = oncothyreon vaccin 10; MUC1 = mucin 1.

An investigational radiopharmaceutical for use in a clinical trial is an investigational medicinal product for which an investigational medicinal product dossier (IMPD) is required in Europe. In the United States, the procedure is similar; an investigational new drug application is submitted instead of an IMPD. The application includes data on product quality and safety. The IMPD is submitted together with the clinical trial application to the competent authority. The IMPD outlines the quality and safety of the investigational radiopharmaceutical based on data gathered during the development process.

In the first phase, on the basis of a good rationale, the radiochemical synthesis-including purification, characterization, initial formulation, and stability -is developed. The result of this phase is a development report, which describes the critical process steps and forms the basis for the subsequent technology transfer step. If tracer development is successful and preclinical data are not yet 
available in the literature, the tracer is evaluated with in vitro and in vivo models to assess its biodistribution and estimate radiation dosimetry. Information from this preclinical evaluation phase is incorporated into the nonclinical pharmacology, pharmacokinetics, and toxicology section and the risk/benefit section of the IMPD. After a decision is made to translate the tracer to the clinical setting, the pharmaceutical or chemistry, manufacturing, and control phase starts. Techniques are transferred from the researchand-development laboratory setting to the good-manufacturingpractice environment. The manufacturing process is described, starting materials are defined, master batch records and testing procedures are documented, and final release specifications and inprocess controls are determined and their justification is described. Next, the analytic methods and the manufacturing process are validated, and the subsequent stability of the final drug product is assessed. The results of the pharmaceutical phase are approved master batch and testing records and validation and stability reports. This information is included in the chemical and pharmaceutical section of the IMPD.

If necessary, a toxicology study is performed, and the results are described in the nonclinical pharmacology, pharmacokinetics, and toxicology section. In the last step, all data are reviewed, and the final IMPD is authorized and submitted to the competent authority. A yearly product quality review and an update of the IMPD are mandatory.

Apart from product and process requirements, other essential elements that ensure final product quality are premises and equipment (qualified and monitored clean rooms, laminar flow hoods, and isolator hot cells); well-trained and qualified personnel; and a good-manufacturing-practice-quality system, including documentation and proper deviation and change in management.

The next step is a first-in-human trial, a small pilot study, for proof of concept and safety. When a tracer is proven safe and considered to be of clinical utility, larger studies with quality controls and standardization steps are required to gain the LoE needed to implement the tracer into the clinical setting. Most of the knowledge about the application of tracers in breast cancer trials concerns ${ }^{18} \mathrm{~F}-\mathrm{FDG},{ }^{18} \mathrm{~F}-\mathrm{FLT}$, and ${ }^{18} \mathrm{~F}-\mathrm{FES}$.

\section{ROLE OF ${ }^{18}$ F-FDG PET IN STANDARD BREAST CANCER CARE}

\section{Screening and Diagnosis}

${ }^{18}$ F-FDG PET scans are not part of current breast cancer screening, given that the lack of spatial resolution and low specificity result in false-positive scans. Better resolution is achievable with positron emission mammography (7), which was approved as a medical device by the U.S. Food and Drug Administration in 2003. It was introduced as a diagnostic adjunct to mammography and breast ultrasound but is still considered investigational, according to Blue Cross Blue Shield Association policy (8). A metaanalysis of 8 studies comprising 873 women with suspected breast cancer showed a pooled sensitivity of $85 \%$ (95\% confidence interval, $83 \%-88 \%$ ) and a specificity per lesion of $79 \%$ (95\% confidence interval, 74\%-83\%) (9) (LoE: 2). In addition, there are 6 ongoing positron emission mammography trials.

\section{Staging}

Besides standard imaging modalities, there is a possible role for ${ }^{18}$ F-FDG PET in initial staging. National Comprehensive Cancer Network guidelines (4) specify no role for ${ }^{18} \mathrm{~F}$-FDG PET in the early stage (I or II) (10-14); European Society for Medical Oncology guidelines (5) suggest the use of ${ }^{18} \mathrm{~F}$-FDG PET/CT in early breast cancer when conventional imaging results are inconclusive. There is limited proof (LoE: 3 ) that ${ }^{18} \mathrm{~F}-\mathrm{FDG}$ PET/CT is helpful for identifying unsuspected regional nodal disease or distant metastases in stage III breast cancer when used in addition to standard staging studies $(12,13,15-19)$. Choosing Wisely recommends refraining from PET scanning during the staging of early breast cancer in individuals at low risk for metastases and in asymptomatic individuals who have been treated for breast cancer with curative intent (20).

${ }^{18} \mathrm{~F}$-FDG PET is not recommended for diagnosing inflammatory breast cancer $(5,21)$ because ${ }^{18} \mathrm{~F}-\mathrm{FDG}$ uptake caused by inflammatory processes decreases tumor specificity (22). However, limited data suggest a possible role of ${ }^{18} \mathrm{~F}$-FDG PET for initial staging (23-25) and predicting survival (26) (LoE: 3).

Guideline recommendations for the use of ${ }^{18} \mathrm{~F}-\mathrm{FDG}$ PET/CT in patients with inoperable breast cancer or metastatic breast cancer (MBC) differ slightly. National Comprehensive Cancer Network guidelines state that the use of ${ }^{18} \mathrm{~F}$-FDG PET or PET/CT scanning is optional, is indicated only for inoperable advanced breast cancer or MBC, and is most helpful when the results of standard imaging studies are equivocal or suspect. Limited evidence supports the use of ${ }^{18}$ F-FDG PET to evaluate the extent of disease in selected patients with recurrent or metastatic disease $(11,12,27,28)$ (LoE: 3). When ${ }^{18}$ F-FDG PET/CT clearly shows bone metastases, no bone scan is needed, because of the high concordance between the modalities for bone metastases (29). European Society for Medical Oncology 2014 guidelines (30) state that ${ }^{18} \mathrm{~F}-\mathrm{FDG}$ PET/CT can be used instead of $\mathrm{CT}$ and bone scanning for inoperable, locally advanced, noninflammatory breast cancer (31) (LoE: 2). Perhaps additional data in future trials can help to better define the indications. Current guidelines do not distinguish between differentiated and undifferentiated tumors. A retrospective analysis showed that hormone receptor-negative tumors had higher SUVs on ${ }^{18} \mathrm{~F}-\mathrm{FDG}$ PET than estrogen receptor (ER)-positive tumors and that uptake in lobular breast cancer was lower than that in ductal breast cancer, leading to false-negative results (32).

Treatment response in trials is often evaluated according to Response Evaluation Criteria In Solid Tumors (RECIST) 1.1; these criteria are largely obtained by anatomic measurements (33) and are based on a collection of data from more than 6,500 trial patients with more than 18,000 target lesions treated in chemotherapy trials. ${ }^{18} \mathrm{~F}$-FDG PET has a role in progressive disease. Besides progressive disease indicated by progression on, for example, a CT scan, progressive disease is also defined as the occurrence of new lesions with positive ${ }^{18} \mathrm{~F}$-FDG PET scan results relative to the results of baseline ${ }^{18} \mathrm{~F}-\mathrm{FDG}$ PET scans. According to RECIST 1.1 , bone metastases are evaluable only if at least $10 \mathrm{~mm}$ of soft tissue is involved. This information implies that MBC patients, more than $65 \%$ of whom develop bone metastases, often cannot be evaluated according to RECIST. Whether repeated ${ }^{18} \mathrm{~F}-\mathrm{FDG}$ PET/CT scans may play a role has yet to be determined.

Measurement of a response earlier than with current anatomic measurements (typically $\sim 8-12 \mathrm{wk}$ ) is of interest because it can reduce the time of ineffective treatment, side effects, and unnecessary costs. In $77 \mathrm{MBC}$ patients receiving neoadjuvant treatment, the metabolic response on ${ }^{18} \mathrm{~F}$-FDG PET/CT after 2 and 6 wk was related to an increased likelihood of a pathologic complete response (34). However, the results were not correlated with overall survival, and multicenter standardization of ${ }^{18} \mathrm{~F}-\mathrm{FDG}$ PET techniques at baseline was not performed.

Fifteen ongoing breast cancer trials expected to accrue more than 1,200 patients are listed at ClinicalTrials.gov; these trials include repeated ${ }^{18} \mathrm{~F}$-FDG PET for early treatment response evaluation. The time frames between the start of treatment and early 
${ }^{18}$ F-FDG response measurements vary from 1 to 4 wk. Furthermore, standardization of techniques and interpretation is not necessarily being attempted. However, it is certainly worth the effort to try to combine the results of these studies as far as the level of standardization allows.

\section{F-FLT PET IN BREAST CANCER}

Imaging of cellular proliferation with ${ }^{18} \mathrm{~F}$-FLT once held great promise for tumor imaging and quantifying a treatment response. However, the facts that the signal intensity is not always high enough and that false-negative and false-positive findings occur result in low sensitivity and specificity in breast cancer (35). On the basis of 11 studies with 189 patients, ${ }^{18} \mathrm{~F}$-FLT PET is not a strong tool for staging or diagnosing breast cancer because of false-negative results for small axillary lymph nodes. It may play a role in predicting a therapy response. However, the results are equivocal (Table 2). Moreover, it is difficult to pool individual patient data given the different outcome measurements and different imaging methods, labeling procedures, and scan protocols used.

\section{${ }^{18}$ F-FES PET IN BREAST CANCER}

Therapy selection for breast cancer patients is mainly based on the presence of the ER, the progesterone receptor, and human epidermal growth factor receptor 2 (HER2). Immunohistochemical (IHC) tumor staining for these receptors is considered to be the gold standard (4,30). In the MBC setting, repeated biopsies are advised because receptor expression can change over time. However, a biopsy does not necessarily capture inter- and intratumoral heterogeneity $(36,37)$.

More than $70 \%$ of breast cancers overexpress the ER. This fact explains the major interest in the $16^{18} \mathrm{~F}$-FES PET studies performed in over 750 breast cancer patients (Table 3). Six studies investigated the correlation between ER immunohistochemistry and ${ }^{18}$ F-FES uptake; the correlation in all of them was good. Predicting the response to endocrine therapy was examined in 8 trials comprising 240 patients. Absence of ${ }^{18} \mathrm{~F}$-FES uptake predicted the failure of endocrine therapy $(38,39)$, and a decrease in uptake during therapy indicated a response to the antihormonal drugs tamoxifen and fulvestrant (40-43).

The results of 11 new studies including an additional 852 patients are expected over the next few years (Table 4). Pooling individual patient data may provide more solid evidence for the role of ${ }^{18} \mathrm{~F}$-FES PET in the clinical setting. However, pooling of data may be challenging given the various tracer dosages, time frames, and reconstructions used.

ER-positive and progesterone receptor-positive tumors showed less uptake of ${ }^{18} \mathrm{~F}-\mathrm{FDG}$ than hormone receptor-negative tumors (32). The role of ${ }^{18} \mathrm{~F}$-FES PET imaging in staging has not yet been proven, but with the knowledge that ${ }^{18} \mathrm{~F}$-FDG PET often shows lower uptake in hormone-positive tumors, it can be hypothesized that ${ }^{18}$ F-FES PET may be of help in staging for patients with such tumors. A trial comparing immunohistochemically determined hormonal status with ${ }^{18} \mathrm{~F}$-FES uptake in MBC patients with hormone receptor-positive or -negative disease before treatment is ongoing (NCT01957332) (44).

\section{MULTICENTER STUDIES AND REPRODUCIBILITY OF RESULTS}

When multicenter studies are started, for all steps in the manufacturing process that are conducted at more than one center, evidence that the final drug products and manufacturing processes are comparable should be provided. This goal could be achieved by cross-validation of the manufacturing processes, including quality control. The National Cancer Institute Cancer Imaging Program has been creating investigational new drugs for use as imaging agents. A subset of the documents filed is being made available to the research community to implement the routine synthesis of tracers at various facilities and to assist investigators with the filing of their own investigational new drugs (45).

A prerequisite for a relevant scan or biomarker for the clinical setting is a high degree of test-retest accordance; in addition, the results of the test should be independent of the hospital at which the test is performed. European Association of Nuclear Medicine procedure guidelines have set rules for harmonizing data and obtaining better reproducibility. The American College of Radiology and the European Association of Nuclear Medicine Research Ltd. accreditation programs, the Society of Nuclear Medicine and Molecular Imaging Clinical Trials Network, and the Quantitative Imaging Biomarkers Alliance of the Radiologic Society of North America are all initiatives to make (molecular) imaging a standardized diagnostic modality in clinical medicine and research. Fortunately, interest in and intention to combine European and U.S. guidelines for molecular imaging to gain more uniform data are growing (46). A retrospective assessment of the compliance of 11 sites with an imaging guideline for ${ }^{18} \mathrm{~F}-\mathrm{FDG}$ PET, however, showed poor compliance, possibly affecting tumor uptake quantification (47). These data show the need for prospective quality control during studies.

A protocol to guide the upfront performance of ${ }^{18}$ F-FDG PET/ CT studies within the context of single- and multiple-center clinical trials has been published (48). It provides standards for all phases of imaging in oncological trials. This Uniform Protocol for Imaging in Clinical Trials is another step toward the larger patient datasets and uniform databases that allow individual patient data meta-analysis. In analogy to the database formed for RECIST, data from different trials can be combined, providing the large patient groups required for solid evidence. Although current guidelines and accreditation programs focus on ${ }^{18} \mathrm{~F}-\mathrm{FDG}$ PET, similar approaches can be used for the new tracers.

\section{TRIAL DESIGNS TO PROVE ROLES OF NEW MOLECULAR IMAGING METHODS IN CLINICAL SETTINGS}

Implementing PET imaging as part of standard care requires proven safety and added benefit beyond existing care. Benefits can include improved patient outcomes as well as reduced costs or physical or emotional burdens on patients. Cost savings could be realized by avoiding surgeries and reducing exposure to ineffective treatments (49).

Implementing PET scanning as a biomarker requires the procedure to score well on criteria such as the REMARK criteria (REporting recommendations for tumor MARKer prognostic studies) (50). These criteria were drafted to guide researchers in reporting their studies for tumor markers in oncology, after it was acknowledged that only a few markers had been adopted into clinical practice. Randomized trials are advised to provide the best LoE in support of a screening or predictive biomarker (50) or to show the actual improved patient outcome of a new diagnostic or prognostic strategy incorporating PET imaging relative to routine care. Unfortunately, standard randomized trials are rarely achievable in the field of predictive markers and molecular imaging because of financial boundaries and the limited capacity of tracer production facilities. 
TABLE 2

${ }^{18}$ F-FLT PET Studies in Patients with Breast Cancer

\begin{tabular}{|c|c|c|c|}
\hline $\begin{array}{l}\text { No. of } \\
\text { patients }\end{array}$ & Study aim(s) & Results & Reference \\
\hline 18 & $\begin{array}{l}\text { Determine whether early changes in }{ }^{18} \mathrm{~F} \text {-FLT PET } \\
\text { can predict benefit from docetaxel }\end{array}$ & $\begin{array}{l}\text { Docetaxel decreased }{ }^{18} \mathrm{~F}-\mathrm{FLT} \text { uptake; early } \\
\text { reduction in tumor SUV correlated with tumor } \\
\text { size changes after } 3 \text { cycles and predicted } \\
\text { midtherapy response }\end{array}$ & 58 \\
\hline 13 & $\begin{array}{l}\text { Define objective criteria for }{ }^{18} \text { F-FLT response and } \\
\text { examine whether }{ }^{18} \text { F-FLT PET can be used to } \\
\text { quantify early response of stage II-IV breast } \\
\text { cancer to FEC }\end{array}$ & $\begin{array}{l}\text { Clinical response at day } 60 \text { was related to } \\
\text { reduction in }{ }^{18} \mathrm{~F}-\mathrm{FLT} \text { uptake at } 1 \mathrm{wk} \\
\text { decreases in } \mathrm{Ki}-67 \text { and } \mathrm{SUV}_{90} \text { at } 1 \mathrm{wk} \\
\text { discriminated between clinical response } \\
\text { and stable disease }\end{array}$ & 59 \\
\hline 15 & $\begin{array}{l}\text { Evaluate whether }{ }^{18} \mathrm{~F}-\mathrm{FLT} \text { PET can predict final } \\
\text { postoperative histopathologic response in } \\
\text { primary locally advanced breast cancer after } \\
1 \text { cycle of NAC }\end{array}$ & Potential utility for early monitoring of response & 60 \\
\hline 28 & $\begin{array}{l}\text { Investigate diagnostic performance of }{ }^{18} \mathrm{~F}-\mathrm{FLT} \text { PET } \\
\text { in women with suspect breast findings on } \\
\text { conventional imaging }\end{array}$ & $\begin{array}{l}\text { SUV of malignant lesions was higher than that } \\
\text { of benign lesions }\end{array}$ & 61 \\
\hline 30 & $\begin{array}{l}\text { Investigate quantitative methods of tumor } \\
\text { proliferation with }{ }^{18} \mathrm{~F}-\mathrm{FLT} \text { PET before and after } \\
\text { single bevacizumab administration and correlate } \\
{ }^{18} \mathrm{~F}-\mathrm{FLT} \text { uptake with } \mathrm{Ki}-67\end{array}$ & ${ }^{18} \mathrm{~F}-\mathrm{FLT}$ uptake decreased after treatment & 62 \\
\hline 20 & $\begin{array}{l}\text { Assess feasibility of }{ }^{18} \mathrm{~F}-\mathrm{FLT} \text { PET/CT for predicting } \\
\text { response to NAC and for comparing baseline } \\
{ }^{18} \mathrm{~F}-\mathrm{FLT} \text { with } \mathrm{Ki}-67\end{array}$ & $\begin{array}{l}\text { No association of baseline, postchemotherapy, } \\
\text { or change in SUV } V_{\max } \text { with pathologic } \\
\text { response to NAC; prechemotherapy Ki- } 67 \\
\text { correlated with SUV } V_{\max }\end{array}$ & 63 \\
\hline 15 & $\begin{array}{l}\text { Validate approach to quantify }{ }^{18} \mathrm{~F}-\mathrm{FLT} \text { PET data } \\
\text { in stage II-IV breast cancer patients and study } \\
\text { whether }{ }^{18} \mathrm{~F}-\mathrm{FLT} \text { PET can predict early treatment } \\
\text { response }\end{array}$ & $\begin{array}{l}\text { Differences before and after therapy in mean } \\
\text { voxel uptake in tumor did not allow complete } \\
\text { responder/nonresponder classification }\end{array}$ & 64 \\
\hline 12 & $\begin{array}{l}\text { Evaluate use of }{ }^{18} \mathrm{~F} \text {-FLT PET for diagnosis of } \\
\text { breast cancer }\end{array}$ & $\begin{array}{l}\text { Totals of } 13 / 14 \text { primary tumors and } 7 / 8 \\
\text { histologically proven lymph node metastases } \\
\text { showed uptake }\end{array}$ & 65 \\
\hline 14 & $\begin{array}{l}\text { Examine side-by-side }{ }^{18} \mathrm{~F}-\mathrm{FDG} \text { imaging and } \\
{ }^{18} \mathrm{~F}-\mathrm{FLT} \text { imaging for monitoring and predicting } \\
\text { chemotherapy response }\end{array}$ & $\begin{array}{l}\text { Mean change in }{ }^{18} \mathrm{~F}-\mathrm{FLT} \text { uptake correlated with } \\
\text { late changes in } \mathrm{CA} 27.29 \text { and } \mathrm{CT} \text { response }\end{array}$ & 66 \\
\hline 10 & $\begin{array}{l}\text { Study feasibility of }{ }^{18} \mathrm{~F}-\mathrm{FLT} \text { PET for breast cancer } \\
\text { visualization }\end{array}$ & $\begin{array}{l}\text { Totals of } 8 / 10 \text { primary tumors and } 2 / 7 \text { axillary } \\
\text { lymph node metastases showed uptake }\end{array}$ & 67 \\
\hline
\end{tabular}

FEC $=$ 5-fluorouracil-epirubicin-cyclophosphamide; Ki-67 = cellular marker for proliferation; NAC $=$ neoadjuvant chemotherapy.

Given these constraints, various approaches to prove the clinical value of PET tracers have been undertaken and can be postulated. In the United States, the National Oncologic PET Registry provided prospective data on the clinical impact in daily practice of over $250,000{ }^{18} \mathrm{~F}$-FDG PET scans (51). It has paved the path to defining relevant indications and reimbursement for ${ }^{18} \mathrm{~F}$ FDG PET. An international registry prospectively collecting data might be able to prove the role of ${ }^{18} \mathrm{~F}$-FES PET, with a likely added benefit in cases of clinical dilemmas $(52,53)$. Such observational data, when gathered with rigorous methodology, can provide solid evidence for diagnostic and prognostic purposes. With regard to PET tracers for therapy response prediction, observational data can also provide important initial evidence. MBC patients may be the prime target population for a study of therapy response prediction because of the importance of the timely identification of noneffective treatment leading to progressive disease. In addition, tracer uptake can be linked to response measurements at a metastasis level instead of at a per-patient level to lead to increased statistical efficiency and to allow smaller proof-of-concept studies.

Ideally, after the standardization of procedures, smaller prospective studies with meaningful direct clinical endpoints can be pooled in a database for individual patient data meta-analysis and further validation, enabling the data for each patient to contribute to an increasing evidence base for PET imaging applications. Next, when evidence is deemed sufficient for a new tracer to be implemented as part of standard care, a stepped wedge cluster randomized trial could provide final evidence of benefit while actually taking advantage of the logistical challenges of implementing novel PET technology (54). In such a trial, hospitals are randomized over a certain period of time to the start of implementation, and at the end of this period, all hospitals will have implemented the PET technology. Patient outcome 
TABLE 3

Studies with ${ }^{18} \mathrm{~F}-\mathrm{FES}$ PET in Breast Cancer Patients

\begin{tabular}{|c|c|c|c|}
\hline $\begin{array}{l}\text { No. of } \\
\text { patients }\end{array}$ & Study aim(s) & Results & Reference \\
\hline 47 & $\begin{array}{l}\text { Quantify tumor }{ }^{18} \mathrm{~F} \text {-FES uptake as predictor of } \\
\text { endocrine therapy response }\end{array}$ & $\begin{array}{l}\text { Absence of uptake predicted failure of } \\
\text { endocrine therapy }\end{array}$ & 38 \\
\hline 19 & $\begin{array}{l}\text { Investigate utility of }{ }^{18} \mathrm{~F}-\mathrm{FES} \mathrm{PET} \text { for predicting overall } \\
\text { response to first-line endocrine therapy in MBC }\end{array}$ & $\begin{array}{l}\text { Low or absent }{ }^{18} \mathrm{~F}-\mathrm{FES} \text { uptake correlated with } \\
\text { lack of ER expression }\end{array}$ & 39 \\
\hline 11 & $\begin{array}{l}\text { Assess serial }{ }^{18} \mathrm{~F}-\mathrm{FES} \text { PET and }{ }^{18} \mathrm{~F}-\mathrm{FDG} \text { PET for } \\
\text { predicting response to tamoxifen }\end{array}$ & $\begin{array}{l}\text { Increase in }{ }^{18} \mathrm{~F}-\mathrm{FDG} \text { uptake and decrease in } \\
{ }^{18} \mathrm{~F}-\mathrm{FES} \text { uptake after start of tamoxifen } \\
\text { predicted response }\end{array}$ & 40 \\
\hline 30 & $\begin{array}{l}\text { Measure changes in }{ }^{18} \mathrm{~F}-\mathrm{FES} \text { uptake with aromatase } \\
\text { inhibitors, tamoxifen, or fulvestrant }\end{array}$ & $\begin{array}{l}\text { No effect with aromatase inhibitors; } ~ 55 \% \\
\text { decrease with tamoxifen or fulvestrant }\end{array}$ & 41 \\
\hline 40 & $\begin{array}{l}\text { Assess serial }{ }^{18} \mathrm{~F}-\mathrm{FES} \text { PET and }{ }^{18} \mathrm{~F}-\mathrm{FDG} \text { PET for } \\
\text { predicting response to tamoxifen }\end{array}$ & $\begin{array}{l}\text { Increase in }{ }^{18} \mathrm{~F}-\mathrm{FDG} \text { uptake and decrease in } \\
{ }^{18} \mathrm{~F}-\mathrm{FES} \text { uptake after start of tamoxifen } \\
\text { predicted response }\end{array}$ & 42 \\
\hline 16 & $\begin{array}{l}\text { Evaluate whether } 500 \mathrm{mg} \text { of fulvestrant optimally } \\
\text { abolishes ER availability in tumor }\end{array}$ & $\begin{array}{l}{ }^{18} \text { F-FES PET showed residual ER availability } \\
\text { during fulvestrant therapy in } 38 \% \text { of } \\
\text { patients; this finding was associated with } \\
\text { early progression }\end{array}$ & 43 \\
\hline 59 & $\begin{array}{l}\text { Investigate whether }{ }^{18} \mathrm{~F}-\mathrm{FES} \mathrm{PET} \text { and serial }{ }^{18} \mathrm{~F}-\mathrm{FDG} \\
\text { PET predict response to endocrine therapy }\end{array}$ & $\begin{array}{l}\text { Baseline }{ }^{18} \mathrm{~F}-\mathrm{FES} \text { uptake and metabolic } \\
\text { flare after estradiol challenge predicted } \\
\text { treatment response }\end{array}$ & 68 \\
\hline 17 & Assess correlation between ${ }^{18} \mathrm{~F}-\mathrm{FES}$ uptake and IHC & Good correlation for ER was observed & 69 \\
\hline 53 & Compare ${ }^{18} \mathrm{~F}$-FES PET with ${ }^{18} \mathrm{~F}-\mathrm{FDG}$ PET and IHC & $\begin{array}{l}{ }^{18} \text { F-FES PET showed } 88 \% \text { agreement with } \\
\text { IHC and provided information not } \\
\text { obtained with }{ }^{18} \text { F-FDG PET }\end{array}$ & 70 \\
\hline 91 & $\begin{array}{l}\text { Measure variability in }{ }^{18} \mathrm{~F}-\mathrm{FES} \text { uptake between and } \\
\text { within patients }\end{array}$ & $\begin{array}{l}\text { Substantial variations in }{ }^{18} \mathrm{~F}-\mathrm{FES} \text { uptake } \\
\text { between and within patients were observed }\end{array}$ & 71 \\
\hline 13 & $\begin{array}{l}\text { Assess feasibility of }{ }^{18} \mathrm{~F} \text {-FES PET for detecting } \\
\text { primary ER-positive breast cancer lesions and } \\
\text { correlation with in vitro status }\end{array}$ & $\begin{array}{l}\text { Focal uptake of }{ }^{18} \mathrm{~F} \text {-FES was seen in all } \\
\text { tumors; uptake correlated well with in } \\
\text { vitro assays }\end{array}$ & 72 \\
\hline 239 & $\begin{array}{l}\text { Assess correlation between }{ }^{18} \mathrm{~F} \text {-FES PET and clinical } \\
\text { and laboratory data, effects of previous treatments, } \\
\text { and }{ }^{18} \mathrm{~F} \text {-FES metabolism }\end{array}$ & $\begin{array}{l}{ }^{18} \mathrm{~F}-\mathrm{FES} \text { uptake correlated positively with BMI } \\
\text { and inversely with plasma sex hormone- } \\
\text { binding globulin levels and binding capacity }\end{array}$ & 73 \\
\hline 18 & $\begin{array}{l}\text { Assess clinical value of dual PET/CT tracers }{ }^{18} \mathrm{~F}-\mathrm{FES} \\
\text { and }{ }^{18} \mathrm{~F} \text {-FDG in predicting response to NAC }\end{array}$ & $\begin{array}{l}{ }^{18} \mathrm{~F}-\mathrm{FES} \text { PET/CT may be feasible for } \\
\text { predicting response to NAC }\end{array}$ & 74 \\
\hline 32 & $\begin{array}{l}\text { Investigate heterogeneity of ER expression among } \\
\text { tumor sites with }{ }^{18} \text { F-FES PET }\end{array}$ & $\begin{array}{l}{ }^{18} \text { F-FES uptake and }{ }^{18} \text { F-FDG uptake varied } \\
\text { greatly within and among patients; }{ }^{18} \mathrm{~F}-\mathrm{FES} \\
\text { PET/CT showed heterogeneous ER } \\
\text { expression }\end{array}$ & 75 \\
\hline 48 & $\begin{array}{l}\text { Correlate }{ }^{18} \mathrm{~F}-\mathrm{FES} \text { PET with ER expression in } \\
\text { patients with primary, operable breast cancer }\end{array}$ & $\begin{array}{l}{ }^{18} \mathrm{~F}-\mathrm{FES} \text { PET SUV correlated with IHC ER } \\
\text { expression; size of primary tumor was } \\
\text { associated with }{ }^{18} \mathrm{~F}-\mathrm{FES} \text { PET SUV }\end{array}$ & 76 \\
\hline 33 & $\begin{array}{l}\text { Evaluate clinical value of }{ }^{18} \mathrm{~F}-\mathrm{FES} \mathrm{PET} / \mathrm{CT} \text { in assisting } \\
\text { with individualized treatment decisions for ER- } \\
\text { positive breast cancer patients }\end{array}$ & $\begin{array}{l}\text { Treatment plan was changed in } 48.5 \% \text { of } \\
\text { cases on basis of }{ }^{18} \text { F-FES PET/CT results }\end{array}$ & 53 \\
\hline
\end{tabular}

and cost-effectiveness data for the old strategy can then be compared with those for the new strategy in a randomized fashion.

There may not be a clear "one-size-fits-all" approach to evaluating the benefit of molecular imaging (55). A prospective, multicenter observational cohort study is taking place in The Netherlands. Its aim is to evaluate the clinical utility of ${ }^{18} \mathrm{~F}-\mathrm{FES}$, ${ }^{89} \mathrm{Zr}$-trastuzumab, and baseline and early ${ }^{18} \mathrm{~F}$-FDG PET scans in 200 MBC patients. Endpoints include the correlation between PET scans and (progression-free) survival, cost-effectiveness, and quality of life. Apart from PET scans, other biomarkers, such as circulating tumor cells and DNA as well as tumor DNA and tumor biopsies, are being analyzed (44). These strategies will allow study of the roles of ${ }^{18} \mathrm{~F}$-FDG, ${ }^{18} \mathrm{~F}$-FES, and ${ }^{89} \mathrm{Zr}$-trastuzumab PET in relation to those of other potential novel biomarkers and will provide information beyond that provided by the standard of care. Another trial will evaluate the clinical utility of ${ }^{18}$ F-FES PET in 99 hormone-positive 
TABLE 4

Ongoing Trials with ${ }^{18}$ F-FES PET at ClinicalTrials.gov

\begin{tabular}{|c|c|c|c|}
\hline Trial identifier & $\begin{array}{l}\text { No. of } \\
\text { patients }\end{array}$ & Primary outcome measures & Secondary outcome measures \\
\hline NCT02409316 & 75 & $\begin{array}{l}\text { Evaluate }{ }^{18} \mathrm{~F} \text {-FES PET/CT uptake as predictor } \\
\text { of PFS in patients who had recurrent cancer } \\
\text { refractory to endocrine therapy or MBC and } \\
\text { were starting new therapy regimen including } \\
\text { endocrine therapy }\end{array}$ & $\begin{array}{l}\text { Correlate }{ }^{18} \mathrm{~F}-\mathrm{FES} \text { uptake, IHC, and } \\
\text { experimental pathology markers } \\
\text { Evaluate utility of combined }{ }^{18} \mathrm{~F}-\mathrm{FES} \text { PET/CT and } \\
{ }^{18} \mathrm{~F}-\mathrm{FDG} \text { PET/CT in identifying heterogeneity of } \\
\text { ER expression and functionality in MBC } \\
\text { Compare }{ }^{18} \mathrm{~F}-\mathrm{FES} \text { uptake at baseline and } \\
\text { progression in patients receiving additional } \\
\text { endocrine therapy } \\
\text { Correlate }{ }^{18} \mathrm{~F}-\mathrm{FES} \text { uptake with CTCs and ratio of } \\
\text { ER+ to ER-CTCs }\end{array}$ \\
\hline NCT01986569 & 94 & $\begin{array}{l}\text { Lesion-level }{ }^{18} \mathrm{~F} \text {-FES PET interpretation and } \\
\text { reference IHC testing in stage IV MBC patients }\end{array}$ & Not provided \\
\hline NCT02398773 & 99 & $\begin{array}{l}\text { Negative predictive value of }{ }^{18} \mathrm{~F}-\mathrm{FES} \text { uptake for } \\
\text { clinical benefit in ER }+, \mathrm{HER} 2-\mathrm{MBC} \text { patients }\end{array}$ & $\begin{array}{l}\text { Evaluate relationship between }{ }^{18} \mathrm{~F}-\mathrm{FES} \text { uptake } \\
\text { and semiquantitative ER measures } \\
{ }^{18} \mathrm{~F}-\mathrm{FES} \mathrm{SUV} \\
\text { for predicting PFS } \\
\text { Percentage of eligible patients for whom biopsy } \\
\text { is not feasible, i.e., predictive accuracy of } \\
{ }^{18} \mathrm{~F}-\mathrm{FES} \text { PET/CT for PFS; significance of } \\
{ }^{18} \mathrm{~F}-\mathrm{FES} \text { PET measures in predicting } \\
\text { progressive disease or clinical benefit }\end{array}$ \\
\hline NCT02149173 & 80 & $\begin{array}{l}\text { Change in }{ }^{18} \mathrm{~F}-\mathrm{FES} \mathrm{SUV} \text { in ER+ MBC patients } \\
\text { undergoing endocrine therapy } \\
\text { Proportion of patients experiencing threshold } \\
\text { as percentage change }\end{array}$ & $\begin{array}{l}\text { Safety profile of }{ }^{18} \mathrm{~F} \text {-FES PET } \\
\text { Correlate }{ }^{18} \mathrm{~F} \text {-FES PET uptake measures with } \\
\text { histopathologic assays and microenvironment } \\
\text { studies of biopsy specimens }\end{array}$ \\
\hline NCT01988324 & 20 & $\begin{array}{l}\text { Concordance between PET results and IHC of } \\
\text { biopsied lesions from ER }+ \text { MBC patients }\end{array}$ & $\begin{array}{l}\text { Numbers of lesions detected on PET vs. CT } \\
\text { and bone scanning } \\
\text { Inter- and intrapatient variations } \\
\text { Interobserver variation }\end{array}$ \\
\hline NCT01627704 & 72 & $\begin{array}{l}\text { Compare response rate after } 6 \text { mo of endocrine } \\
\text { treatment in } \mathrm{MBC} \text { patients with }{ }^{18} \mathrm{~F}-\mathrm{FES} \\
\text { uptake in metastatic lesions }\end{array}$ & $\begin{array}{l}\text { Determine whether }{ }^{18} \mathrm{~F}-\mathrm{FES} \text { PET/CT is able to } \\
\text { detect metastases that are not visible on } \\
{ }^{18} \mathrm{~F}-\mathrm{FDG} \text { PET/CT; determine nature of } \\
\text { discordant }{ }^{18} \mathrm{~F}-\mathrm{FES} \text { and }{ }^{18} \mathrm{~F}-\mathrm{FDG} \text { foci; } \\
\text { validate and improve interpretation criteria } \\
\text { for }{ }^{18} \mathrm{~F}-\mathrm{FES} \mathrm{PET/CT;} \mathrm{confirm} \mathrm{tolerance}\end{array}$ \\
\hline NCT00816582 & 100 & Rate of clinical benefit of fulvestrant in MBC patients & Not provided \\
\hline NCT00647790 & 79 & $\begin{array}{l}\text { Preoperatively evaluate ER status of breast } \\
\text { cancer on PET imaging in primary breast } \\
\text { cancer patients undergoing surgery }\end{array}$ & $\begin{array}{l}\text { Correlate ER positivity on PET imaging and } \\
\text { conventional IHC }\end{array}$ \\
\hline NCT01153672 & 8 & $\begin{array}{l}\text { Determine rate of clinical benefit for patients } \\
\text { treated with cycles of } 2 \text { wk of vorinostat and } \\
\text { then } 6 \text { wk of aromatase inhibitor }\end{array}$ & $\begin{array}{l}\text { Change in }{ }^{18} \text { F-FES SUV after } 2 \text { and } 8 w k \\
\text { Change in }{ }^{18} \text { F-FDG SUV after } 2 \text { and } 8 w k\end{array}$ \\
\hline NCT01275859 & 25 & $\begin{array}{l}\text { Evaluate rate of pathologic complete response to } \\
\text { lapatinib plus letrozole in neoadjuvant setting }\end{array}$ & $\begin{array}{l}\text { Correlation of }{ }^{18} \mathrm{~F} \text {-FES PET with biologic and } \\
\text { imaging predictors of response } \\
\text { Evaluate diagnostic value of }{ }^{18} \mathrm{~F}-\mathrm{FES} \text { PET SUV } \\
\text { for predicting response to therapy }\end{array}$ \\
\hline NCT01957332 & 200 & $\begin{array}{l}\text { Evaluate clinical utility of experimental PET } \\
\text { scans in setting of MBC at first presentation }\end{array}$ & $\begin{array}{l}\text { Correlation PET scans with (progression-free) } \\
\text { survival } \\
\text { Cost-effectiveness of molecular imaging } \\
\text { Quality of life }\end{array}$ \\
\hline
\end{tabular}

PFS = progression-free survival; IHC = immunohistochemistry; CTCs = circulating tumor cells; ER $+=$ estrogen receptor-positive; ER- = estrogen receptor-negative. 
MBC patients and its possible role, relative to that of ${ }^{18} \mathrm{~F}$-FDG PET, in predicting a response to therapy (NCT02398773).

Cost-effectiveness can be assessed in comparison with standard options and costs per life-year saved. Data on the cost-effectiveness of ${ }^{18} \mathrm{~F}$-FDG PET in breast cancer patients are limited. Computer models can be used to conduct cost-effectiveness studies (56). In silico simulation studies could help optimize future studies. Such studies assist with the use of the smallest number of patients and thus with generating the lowest costs to obtain a meaningful response prediction signature. Simulated data not only can provide more information concerning the number of patients needed but also can help define thresholds for outcomes as well as define the optimal statistical analysis approach. The first attempt to assess added benefit in terms of the cost-effectiveness of ${ }^{18} \mathrm{~F}$-FES PET was made by simulating the follow-up for $5 \mathrm{y}$ of women with ER-positive MBC (57). The total costs for the ${ }^{18} \mathrm{~F}-\mathrm{FES}$ PET/CT strategy were higher than those for the standard workup or ${ }^{18}$ F-FDG PET/CT. Nonetheless, the total number of performed diagnostic tests was smaller for each of the PET/CT strategies than for the standard workup.

\section{CONCLUSION}

Important steps have been taken in the field of breast cancer, especially for ${ }^{18} \mathrm{~F}$-FDG PET, leading to its role in daily practice. For other potential interesting tracers in the field of breast cancer, the path to the clinical setting can be facilitated through multidisciplinary efforts. Information on tracer development and investigational new drugs can be shared. Moreover, when data collection and scanning procedures are harmonized, measurements are standardized, and all procedures are documented carefully, an incremental valuable database can be developed. Optimal documentation and standardization can be supported by a standardized scan and analysis report form. The analysis of such database data can provide guidance regarding the optimal application, show what kind of additional evidence is needed (such as early health technology assessment), prioritize studies to provide this evidence, and provide important support and sufficient LoE—ultimately focusing and expediting implementation studies. Once multiple PET tracers have been incorporated into standard breast cancer care, the use of a combination may even provide more complete insight in individuals. Scans will provide information about molecular characteristics and heterogeneity across lesions in the body. This process may contribute significantly to superior personalized treatment through several new potential treatment options for breast cancer.

\section{DISCLOSURE}

This research was supported by Dutch Cancer Society grant RUG 2012-5565; advanced grant OnQView 676339; and research grants from Roche/Genentech, Amgen, Novartis, Pieris, Servier, and AstraZeneca to the University Medical Center Groningen, University of Groningen. Elizabeth G.E de Vries is co-chair of the RECIST committee and is on the data monitoring committee for Biomarin and the advisory board for Synthon. Geke A.P. Hospers is on the advisory boards for Roche, BMS, MSD, and Amgen. No other potential conflict of interest relevant to this article was reported.

\section{REFERENCES}

1. Zardavas D, Irrthum A, Swanton C, Piccart M. Clinical management of breast cancer heterogeneity. Nat Rev Clin Oncol. 2015;12:381-394.

2. McGranahan N, Swanton C. Biological and therapeutic impact of intratumor heterogeneity in cancer evolution. Cancer Cell. 2015;27:15-26.
3. Alam IS, Arshad MA, Nguyen Q-D, Aboagye EO. Radiopharmaceuticals as probes to characterize tumour tissue. Eur J Nucl Med Mol Imaging. 2015;42:537-561.

4. National Comprehensive Cancer Network. NCCN guidelines. www.nccn.org/ professionals/physician_gls/f_guidelines.asp\#breast. Accessed December 8, 2015.

5. Cardoso F, Harbeck N, Fallowfield L, Kyriakides S, Senkus E; ESMO Guidelines Working Group. Locally recurrent or metastatic breast cancer: ESMO Clinical Practice Guidelines for diagnosis, treatment and follow-up. Ann Oncol. 2012;23 (suppl 7):vii11-vii19.

6. Centre for Evidence-Based Medicine. OCEBM levels of evidence. http://www. cebm.net/index.aspx?o=5653. Accessed December 8, 2015.

7. MacDonald L, Edwards J, Lewellen T, Haseley D, Rogers J, Kinahan P. Clinical imaging characteristics of the positron emission mammography camera: PEM Flex Solo II. J Nucl Med. 2009;50:1666-1675.

8. Blue Cross Blue Shield Association; Kaiser Permanente. Special report: screening asymptomatic women with dense breasts and normal mammograms for breast cancer. Technol Eval Cent Assess Program Exec Summ. 2014;28:1-2.

9. Caldarella C, Treglia G, Giordano A. Diagnostic performance of dedicated positron emission mammography using fluorine-18-fluorodeoxyglucose in women with suspicious breast lesions: a meta-analysis. Clin Breast Cancer. 2014;14:241-248.

10. Kumar R, Chauhan A, Zhuang H, Chandra P, Schnall M, Alavi A. Clinicopathologic factors associated with false negative FDG-PET in primary breast cancer. Breast Cancer Res Treat. 2006;98:267-274.

11. Podoloff DA, Advani RH, Allred C, et al. NCCN task force report: positron emission tomography/computed tomography scanning in cancer. J Natl Compr Canc Netw. 2007;5(suppl 1):S1-S22.

12. Rosen EL, Eubank WB, Mankoff DA. FDG PET, PET/CT, and breast cancer imaging. Radiographics. 2007;27(suppl 1):S215-S229.

13. Wahl RL, Siegel BA, Coleman RE, Gatsonis CG; PET Study Group. Prospective multicenter study of axillary nodal staging by positron emission tomography in breast cancer: a report of the Staging Breast Cancer With PET Study Group. J Clin Oncol. 2004;22:277-285.

14. Cermik TF, Mavi A, Basu S, Alavi A. Impact of FDG PET on the preoperative staging of newly diagnosed breast cancer. Eur J Nucl Med Mol Imaging. 2008; $35: 475-483$.

15. Aukema TS, Straver ME, Peeters MJ, et al. Detection of extra-axillary lymph node involvement with FDG PET/CT in patients with stage II-III breast cancer. Eur J Cancer. 2010;46:3205-3210.

16. Groheux D, Moretti JL, Baillet G, et al. Effect of ${ }^{18}$ F-FDG PET/CT imaging in patients with clinical stage II and III breast cancer. Int J Radiat Oncol Biol Phys. 2008;71:695-704.

17. Niikura N, Costelloe CM, Madewell JE, et al. FDG-PET/CT compared with conventional imaging in the detection of distant metastases of primary breast cancer. Oncologist. 2011;16:1111-1119.

18. van der Hoeven JJ, Krak NC, Hoekstra OS, et al. ${ }^{18}$ F-2-fluoro-2-deoxy-D-glucose positron emission tomography in staging of locally advanced breast cancer. J Clin Oncol. 2004;22:1253-1259.

19. Fuster D, Duch J, Paredes P, et al. Preoperative staging of large primary breast cancer with $\left[{ }^{18} \mathrm{~F}\right]$ fluorodeoxyglucose positron emission tomography/computed tomography compared with conventional imaging procedures. J Clin Oncol. 2008;26:4746-4751.

20. ABIM Foundation. Choosing Wisely. http://www.choosingwisely.org/. Accessed December 8, 2015.

21. Dawood S, Merajver SD, Viens P, et al. International expert panel on inflammatory breast cancer: consensus statement for standardized diagnosis and treatment. Ann Oncol. 2011;22:515-523.

22. Metser U, Even-Sapir E. Increased ${ }^{18} \mathrm{~F}$-fluorodeoxyglucose uptake in benign, nonphysiologic lesions found on whole-body positron emission tomography/ computed tomography: accumulated data from four years of experience with PET/CT. Semin Nucl Med. 2007;37:206-222.

23. Alberini JL, Lerebours F, Wartski M, et al. ${ }^{18} \mathrm{~F}$-fluorodeoxyglucose positron emission tomography/computed tomography imaging in the staging and prognosis of inflammatory breast cancer. Cancer. 2009;115:5038-5047.

24. Champion L, Lerebours F, Cherel P, et al. ${ }^{18}$ F-FDG PET/CT imaging versus dynamic contrast-enhanced CT for staging and prognosis of inflammatory breast cancer. Eur J Nucl Med Mol Imaging. 2013;40:1206-1213.

25. Groheux D, Giacchetti S, Delord M, et al. ${ }^{18}$ F-FDG PET/CT in staging patients with locally advanced or inflammatory breast cancer: comparison to conventional staging. J Nucl Med. 2013;54:5-11.

26. Carkaci S, Sherman CT, Ozkan E, et al. ${ }^{18}$ F-FDG PET/CT predicts survival in patients with inflammatory breast cancer undergoing neoadjuvant chemotherapy. Eur J Nucl Med Mol Imaging. 2013;40:1809-1816.

27. Eubank WB, Mankoff D, Bhattacharya M, et al. Impact of FDG PET on defining the extent of disease and on the treatment of patients with recurrent or metastatic breast cancer. AJR. 2004;183:479-486. 
28. Moon DH, Maddahi J, Silverman DH, Glaspy JA, Phelps ME, Hoh CK. Accuracy of whole-body fluorine-18-FDG PET for the detection of recurrent or metastatic breast carcinoma. J Nucl Med. 1998;39:431-435.

29. Morris PG, Lynch C, Feeney JN, et al. Integrated positron emission tomography/ computed tomography may render bone scintigraphy unnecessary to investigate suspected metastatic breast cancer. J Clin Oncol. 2010;28:3154-3159.

30. Cardoso F, Costa A, Norton L, et al. ESO-ESMO 2nd international consensus guidelines for advanced breast cancer (ABC2). Breast. 2014;23:489-502.

31. Brennan ME, Houssami N. Evaluation of the evidence on staging imaging for detection of asymptomatic distant metastases in newly diagnosed breast cancer. Breast. 2012;21:112-123.

32. Groheux D, Majdoub M, Tixier F, et al. Do clinical, histological or immunohistochemical primary tumour characteristics translate into different ${ }^{18} \mathrm{~F}-\mathrm{FDG}$ PET/ CT volumetric and heterogeneity features in stage II/III breast cancer? Eur $J$ Nucl Med Mol Imaging. 2015;42:1682-1691.

33. Eisenhauer EA, Therasse P, Bogaerts J, et al. New response evaluation criteria in solid tumours: revised RECIST guideline (version 1.1). Eur J Cancer. 2009;45: 228-247.

34. Gebhart G, Gamez C, Holmes E, et al. ${ }^{18}$ F-FDG PET/CT for early prediction of response to neoadjuvant lapatinib, trastuzumab, and their combination in HER2positive breast cancer: results from neo-ALTTO. J Nucl Med. 2013;54:18621868.

35. Deng SM, Zhang W, Zhang B, Wu YW. Assessment of tumor response to chemotherapy in patients with breast cancer using ${ }^{18}$ F-FLT: a meta-analysis. Chin J Cancer Res. 2014;26:517-524.

36. Hoefnagel LD, van de Vijver MJ, van Slooten HJ, et al. Receptor conversion in distant breast cancer metastases. Breast Cancer Res. 2010;12:R75.

37. Chung GG, Zerkowski MP, Ghosh S, Camp RL, Rimm DL. Quantitative analysis of estrogen receptor heterogeneity in breast cancer. Lab Invest. 2007;87:662-669.

38. Linden HM, Stekhova SA, Link JM, et al. Quantitative fluoroestradiol positron emission tomography imaging predicts response to endocrine treatment in breast cancer. J Clin Oncol. 2006;24:2793-2799.

39. Peterson LM, Kurland BF, Schubert EK, et al. A phase 2 study of $16 \alpha-\left[{ }^{18} \mathrm{~F}\right]-$ fluoro-17 $\beta$-estradiol positron emission tomography as a marker of hormone sensitivity in metastatic breast cancer. Mol Imaging Biol. 2014;16:431-440.

40. Dehdashti F, Flanagan FL, Mortimer JE, Katzenellenbogen JA, Welch MJ, Siegel BA. Positron emission tomographic assessment of "metabolic flare" to predict response of metastatic breast cancer to antiestrogen therapy. Eur J Nucl Med. 1999;26:51-56.

41. Linden HM, Kurland BF, Peterson LM, et al. Fluoroestradiol positron emission tomography reveals differences in pharmacodynamics of aromatase inhibitors, tamoxifen, and fulvestrant in patients with metastatic breast cancer. Clin Cancer Res. 2011;17:4799-4805.

42. Mortimer JE, Dehdashti F, Siegel BA, Trinkaus K, Katzenellenbogen JA, Welch MJ. Metabolic flare: indicator of hormone responsiveness in advanced breast cancer. J Clin Oncol. 2001;19:2797-2803

43. van Kruchten M, de Vries EG, Glaudemans AW, et al. Measuring residual estrogen receptor availability during fulvestrant therapy in patients with metastatic breast cancer. Cancer Discov. 2015;5:72-81.

44. Bensch F, Brouwers A, Glaudemans A, et al. IMPACT: IMaging PAtients for Cancer drug selecTion-metastatic breast cancer (MBC) [abstract]. Cancer Res. 2015;75:OT3-2-01

45. IND regulatory \& manufacturing resources. National Cancer Institute website. http://imaging.cancer.gov/programsandresources/cancer-tracer-synthesis-resources. Accessed December 10, 2015.

46. EANM Research Ltd. (EARL). European Association of Nuclear Medicine website. http://earl.eanm.org/cms/website.php?id=/en/projects/fdg_pet_ct_accreditation. Accessed December 8, 2015.

47. Hristova I, Boellaard R, Vogel W, et al. Retrospective quality control review of FDG scans in the imaging sub-study of PALETTE EORTC 62072/VEG110727: a randomized, double-blind, placebo-controlled phase III trial. Eur J Nucl Med Mol Imaging. 2015;42:848-857.

48. Graham MM, Wahl RL, Hoffman JM, et al. Summary of the UPICT protocol for ${ }^{18}$ F-FDG PET/CT imaging in oncology clinical trials. J Nucl Med. 2015;56:955-961.

49. Buck AK, Herrmann K, Stargardt T, Dechow T, Krause BJ, Schreyogg J. Economic evaluation of PET and PET/CT in oncology: evidence and methodologic approaches. J Nucl Med Technol. 2010;38:6-17.

50. McShane LM, Altman DG, Sauerbrei W, et al. Reporting recommendations for tumor marker prognostic studies. J Clin Oncol. 2005;23:9067-9072.

51. Monthly status report. National Oncologic PET Registry website. https://www. cancerpetregistry.org/status.htm. Accessed December 10, 2015.

52. Sun Y, Yang Z, Zhang Y, et al. The preliminary study of $16 \alpha-\left[{ }^{18} \mathrm{~F}\right]$ fluoroestradiol PET/CT in assisting the individualized treatment decisions of breast cancer patients. PLoS One. 2015;10:e116341.
53. van Kruchten M, Glaudemans AW, de Vries EF, et al. PET imaging of estrogen receptors as a diagnostic tool for breast cancer patients presenting with a clinical dilemma. J Nucl Med. 2012;53:182-190.

54. Hemming K, Haines TP, Chilton PJ, Girling AJ, Lilford RJ. The stepped wedge cluster randomised trial: rationale, design, analysis, and reporting. BMJ. 2015;350:h391.

55. Koninklijke Nederlandse Akademie van Wetenschappen. Evaluation of new technology in health care. http://knaw.nl/nl/actueel/publicaties/evaluation-ofnew-technology-in-health-care. 2014. Accessed December 8, 2015.

56. Moons KG, Altman DG, Vergouwe Y, Royston P. Prognosis and prognostic research: application and impact of prognostic models in clinical practice. BMJ. 2009;338:b606.

57. Koleva-Kolarova RG, Greuter MJ, van Kruchten M, et al. The value of PET/CT with FES or FDG tracers in metastatic breast cancer: a computer simulation study in ER-positive patients. Br J Cancer. 2015;112:1617-1625.

58. Contractor KB, Kenny LM, Stebbing J, et al. ${ }^{18} \mathrm{~F}-3$ 'deoxy-3'-fluorothymidine positron emission tomography and breast cancer response to docetaxel. Clin Cancer Res. 2011;17:7664-7672.

59. Kenny L, Coombes RC, Vigushin DM, Al-Nahhas A, Shousha S, Aboagye EO. Imaging early changes in proliferation at 1 week post chemotherapy: a pilot study in breast cancer patients with $3^{\prime}$-deoxy- $3^{\prime}-\left[{ }^{18} \mathrm{~F}\right]$ fluorothymidine positron emission tomography. Eur J Nucl Med Mol Imaging. 2007;34:1339-1347.

60. Crippa F, Agresti R, Sandri M, et al. ${ }^{18}$ F-FLT PET/CT as an imaging tool for early prediction of pathological response in patients with locally advanced breast cancer treated with neoadjuvant chemotherapy: a pilot study. Eur J Nucl Med Mol Imaging. 2015;42:818-830.

61. Wang J, Kuo WH, Shih TT, Yen RF. Using ${ }^{18}$ F-FLT PET to distinguish between malignant and benign breast lesions with suspicious findings in mammography and breast ultrasound. Ann Nucl Med. 2014;28:941-949.

62. Marti-Climent JM, Dominguez-Prado I, Garcia-Velloso MJ, et al. $\left[{ }^{18} \mathrm{~F}\right]$ fluorothymidinepositron emission tomography in patients with locally advanced breast cancer under bevacizumab treatment: usefulness of different quantitative methods of tumor proliferation. Rev Esp Med Nucl Imagen Mol. 2014;33:280-285.

63. Woolf DK, Beresford M, Li SP, et al. Evaluation of FLT-PET-CT as an imaging biomarker of proliferation in primary breast cancer. Br J Cancer. 2014;110: 2847-2854.

64. Veronese M, Rizzo G, Aboagye EO, Bertoldo A. Parametric imaging of ${ }^{18} \mathrm{~F}-$ fluoro-3-deoxy-3-1-fluorothymidine PET data to investigate tumour heterogeneity. Eur J Nucl Med Mol Imaging. 2014;41:1781-1792.

65. Smyczek-Gargya B, Fersis N, Dittmann H, et al. PET with ${ }^{18}$ F-fluorothymidine for imaging of primary breast cancer: a pilot study. Eur J Nucl Med Mol Imaging. 2004;31:720-724.

66. Pio BS, Park CK, Pietras R, et al. Usefulness of $3^{\prime}$-[F-18]fluoro-3'-deoxythymidine with positron emission tomography in predicting breast cancer response to therapy. Mol Imaging Biol. 2006;8:36-42.

67. Been LB, Elsinga PH, de Vries J, et al. Positron emission tomography in patients with breast cancer using ${ }^{18} \mathrm{~F}-3^{\prime}$-deoxy-3'-fluoro-1-thymidine: a pilot study. Eur $J$ Surg Oncol. 2006;32:39-43.

68. Dehdashti F, Mortimer JE, Trinkaus K, et al. PET-based estradiol challenge as a predictive biomarker of response to endocrine therapy in women with estrogenreceptor-positive breast cancer. Breast Cancer Res Treat. 2009;113:509-517.

69. Peterson LM, Mankoff DA, Lawton T, et al. Quantitative imaging of estrogen receptor expression in breast cancer with PET and ${ }^{18} \mathrm{~F}$-fluoroestradiol. $\mathrm{J}$ Nucl Med. 2008;49:367-374.

70. Dehdashti F, Mortimer JE, Siegel BA, et al. Positron tomographic assessment of estrogen receptors in breast cancer: comparison with FDG-PET and in vitro receptor assays. J Nucl Med. 1995;36:1766-1774.

71. Kurland BF, Peterson LM, Lee JH, et al. Between-patient and within-patient (site-to-site) variability in estrogen receptor binding, measured in vivo by ${ }^{18} \mathrm{~F}-$ fluoroestradiol PET. J Nucl Med. 2011;52:1541-1549.

72. Mintun MA, Welch MJ, Siegel BA, et al. Breast cancer: PET imaging of estrogen receptors. Radiology. 1988;169:45-48.

73. Peterson LM, Kurland BF, Link JM, et al. Factors influencing the uptake of ${ }^{18} \mathrm{~F}-$ fluoroestradiol in patients with estrogen receptor positive breast cancer. Nucl Med Biol. 2011;38:969-978.

74. Yang Z, Sun Y, Xue J, et al. Can positron emission tomography/computed tomography with the dual tracers fluorine-18 fluoroestradiol and fluorodeoxyglucose predict neoadjuvant chemotherapy response of breast cancer? A pilot study. PLoS One. 2013;8:e78192.

75. Yang Z, Sun Y, Zhang Y, et al. Can fluorine-18 fluoroestradiol positron emission tomography-computed tomography demonstrate the heterogeneity of breast cancer in vivo? Clin Breast Cancer. 2013;13:359-363.

76. Gemignani ML, Patil S, Seshan VE, et al. Feasibility and predictability of perioperative PET and estrogen receptor ligand in patients with invasive breast cancer. J Nucl Med. 2013;54:1697-1702. 